\title{
HISTOMORPHOLOGICAL PATTERN OF NON-NEOPLASTIC AND PRE-NEOPLASTIC LESIONS OF CERVIX
}

\author{
Rubal Jain 1 , Rajendra Kumar Nigam², Reeni Malik3 ${ }^{3}$ Pramila Jain 4 , V. K. Trichal5, Atul Shrivastava6
}

${ }_{1}^{1}$ Final Year Student, Department of Pathology, Gandhi Medical College, Bhopal, Madhya Pradesh.

2 Professor, Department of Pathology, Gandhi Medical College, Bhopal, Madhya Pradesh.

3 Professor and HOD, Department of Pathology, Gandhi Medical College, Bhopal, Madhya Pradesh.

${ }^{4}$ Associate Professor, Department of Pathology, Gandhi Medical College, Bhopal, Madhya Pradesh.

${ }^{5}$ Associate Professor, Department of Pathology, Gandhi Medical College, Bhopal, Madhya Pradesh.

${ }_{6}^{6}$ Senior Resident Officer, Department of Population Based Cancer Registry, ICMR, Gandhi Medical College, Bhopal, Madhya Pradesh.

\section{ABSTRACT}

\section{BACKGROUND}

Specimens from cervix constitute a major contributor of gynaecological tissue received for histomorphological evaluation. Benign lesions presents with varied clinical presentations and age distribution. Lesions such as dysplasia and Cervical Intraepithelial Lesions are a precursor to malignancies which have a high mortality and morbidity among Indian women.

\section{AIMS}

To study pattern of non-neoplastic and pre-neoplastic lesions of cervix and their correlation with age, symptoms, gravida, socioeconomic parameters and personal habits.

\section{METHODS AND MATERIAL}

A retrospective study was done in Department of Pathology, Gandhi Medical College, Bhopal, Madhya Pradesh from January 2014 to August 2015.

\section{STATISTICAL ANALYSIS}

Program epi info and SSPS were used to evaluate data.

\section{RESULTS AND CONCLUSIONS}

195 cases were evaluated with peak cases presenting in 4th decade. Chronic nonspecific cervicitis (175 cases) was the most common histomorphological diagnosis and only 5 cases of Cervical Intraepithelial Lesions were reported, though 180 cases of cervical cancers were reported during the same time period highlighting the need to bridge the gap with early diagnosis and treatment of pre-malignant lesions.

\section{KEYWORDS}

Benign, Cervix, Histomorphology, Chronic Cervicitis.

HOW TO CITE THIS ARTICLE: Jain R, Nigam RK, Malik R, et al. Histomorphological pattern of non-neoplastic and pre-neoplastic lesions of cervix. J. Evolution Med. Dent. Sci. 2016;5(68):4909-4913, DOI: 10.14260/jemds/2016/1116

\section{INTRODUCTION}

Cervical cancers constitute a major health problem among Indian women. It is preceded by Cervical Intraepithelial Lesions; in fact it is one of the few cancerous lesions in which precursor lesions have been extensively researched and studied. The non- and pre-neoplastic lesions have a wide age distribution and often presents late since most cases are asymptomatic. These lesions are amenable to treatment and early detection of pre-neoplastic cases could reduce the cervical cancers incidence considerably. Cervices from hysterectomies and biopsies constitute the majority of gynaecological specimens, which are received in the Department of Histopathology. Owing to varied frequency of various lesions in different geographic regions within our

Financial or Other, Competing Interest: None.

Submission 23-06-2016, Peer Review 12-08-2016,

Acceptance 17-08-2016, Published 25-08-2016.

Corresponding Author:

Dr. Rubal Jain,

C/o. Mr. H. K. Vijayvargiye,

$1^{\text {st }}$ Floor, A-152, Shahpura,

Behind Shekhar Hospital,

Bhopal-462016,

Madhya Pradesh.

E-mail: drrubaljain@gmail.com

DOI: $10.14260 /$ jemds/2016/1116

country, understanding the histopathological pattern of these lesions will help in the management of the patient. Cytological screening programs for cervical cancers have not yet achieved their goal due to lack of coverage, faulty sampling and processing and paucity of pathologists as well as discordance in reporting of same slide. Therefore, the histopathological examination of the biopsies of cervical lesions is the single best gold standard for the diagnosis of the lesions of the cervix.[1]

The aim of the following study is to establish the frequency and histopathological types of non-neoplastic and preneoplastic cervical lesions of the cervix in our institute. It is hoped that data obtained from our research will be useful in the management of these lesions as well as will serve baseline for further research pertaining to this topic.

\section{MATERIALS AND METHODS}

A retrospective study was conducted in the Department of Pathology, Gandhi Medical College, Bhopal, Madhya Pradesh from 1st January 2014 - 31 ${ }^{\text {st }}$ August 2015.

All the cervical biopsies and hysterectomy specimens with adequate tissue received in Department of Pathology for cervical lesions were evaluated. All non- and pre-neoplastic lesions were included, while all neoplastic cases were excluded from the study. All samples under study were received in $10 \%$ formalin, routinely processed according to 
standard techniques after grossing. The wax blocks of tissue were cut using microtome and mounted on slides followed by staining procedure (Haematoxylin and Eosin) and reported by faculty of department. Relevant data like age, clinical history, parity, gravida, menstrual history, personnel hygiene, etc. were obtained from requisition forms as well as case files as and when required. Ethical clearance was received from Institute's Ethical Committee. Statistical Analysis of Data was analysed using appropriate statistical tests using software epiinfo and SSPS.

\section{RESULTS}

A total of 375 cases were evaluated. Out of these, 195 (52\%) cases were in non-neoplastic and pre-neoplastic category and $180(48 \%)$ cases were neoplastic category. Incidence of nonneoplastic lesions was higher than neoplastic lesions. Chronic non-specific cervicitis was the most common histological diagnosis made with 175 cases. Distribution of as in Table 1.

The histomorphological distribution pattern of benign lesions comprising of non-neoplastic and pre-neoplastic $(195$ cases) was as follows (Table 2).

Thus, non-neoplastic and pre-neoplastic lesions comprised of $176(90.3 \%)$ and 19 (9.7\%) cases respectively. Only one case of granulomatous cervicitis was reported, the sections revealed multiple caseating granulomas surrounded by epithelioid cells and mononuclear cells along with fibrin stands. The underlying aetiology was most probably tubercular considering the fact that the patient had history of contact with a known sputum positive tuberculosis cases as well as the geographical and aetiological background of patients in patients reporting in our institute.

The cases of chronic cervicitis constituting the majority chunk showed erosion of surface epithelium, congestion, mild inflammatory infiltrate as well as squamous metaplasia in majority of cases.

14 cases of cervical dysplasia were reported along with 5 cases of CIN cases.

\section{Lesions of Cervix and their Correlation with Age}

The age distribution for benign cervical lesions peaked in 4th decade with 68 (34.9\%) cases. The following observations were made regarding the mean age of patients in 2 broad histological categories in this study (Table 3).

Age distribution of lesions was also studied extensively to infer the pattern and presentations. The mean age of cases increased hierarchically as the spectrum progressed from chronic non-specific cervicitis to CIN. The mean age of chronic non-specific cervicitis was 40.8 years with cases ranging from 22 to 65 years, while that of dysplasia was 47.1 years and range was 33 years to 65 years. Thus dysplasia cases were encountered a decade later than chronic cervicitis. CIN cases had a mean age of 57.2 years and all the cases presented in late 5 th and early 6 th decade.

\section{Clinical Presentation of Cervical Lesions}

The clinical presentation of women was varied. Most common clinical presentation was white discharge with or without lower abdominal pain (47.69\%) followed by lower abdominal pain only $(26.66 \%)$ and abnormal bleeding/spotting (13.84\%). Only $10.77 \%$ cases had complained of postmenopausal bleeding, while only $1.03 \%$ cases presented with pyometra. Clinical presentation in varied lesions was as in Table 4.

\section{Gravida}

Average Gravida of females increased successively from 2.9 in non-neoplastic, 3.47 in pre-neoplastic category. The distribution is as in Table 5.

\section{Abortions}

Regarding number of abortions $71.28 \%$ had nil abortions, $22.56 \%$ had single and a mere $6.15 \%$ had 2 or more abortions in their lifetime and were statistically insignificant.

\section{Distribution of Rural and Urban Population}

Our study group comprised of population from both rural and urban areas. There was no significant difference in the distribution of cervical diagnosis with regards to area of residence apart from the fact that women of urban area had more accessible health services and better treatment followup than their rural counterparts; 97 (49.74\%) patients were from rural background.

\section{Other Factors}

Majority of females had poor personnel hygiene habits. Only $4 \%$ used oral contraceptives, a minority used barrier method, while majority used no contraceptives and underwent total tubectomy after family completion.

Majority of women in our study had menarche at 12-13 years of age and had first sexual exposure before the age of 20 years. A majority of them also had their first conception before reaching 20 years and almost all had completed their family in 2nd decade.

None of the women were immunised with human papilloma virus vaccine. Also, awareness regarding the same was almost non-existent.

\begin{tabular}{|c|c|c|}
\hline $\begin{array}{c}\text { Broad Category of } \\
\text { Cervical Lesions }\end{array}$ & $\begin{array}{c}\text { No. of } \\
\text { Cases }\end{array}$ & $\begin{array}{c}\text { Percentage } \\
\mathbf{\%}\end{array}$ \\
\hline Non-neoplastic & 176 & $90.25 \%$ \\
\hline Pre-neoplastic & 19 & $9.75 \%$ \\
\hline Total & $\mathbf{1 9 5}$ & $\mathbf{1 0 0 \%}$ \\
\hline Table 1: Distribution Lesions of Cervix
\end{tabular}

\begin{tabular}{|c|c|c|}
\hline Diagnosis & $\begin{array}{l}\text { No. of } \\
\text { Cases }\end{array}$ & $\begin{array}{c}\text { Percentage } \\
\%\end{array}$ \\
\hline Chronic Cervicitis & 175 & $89.74 \%$ \\
\hline $\begin{array}{c}\text { Chronic Cervicitis with } \\
\text { Dysplasia }\end{array}$ & 14 & $7.18 \%$ \\
\hline CIN3 & 2 & $1.03 \%$ \\
\hline CIN2 & 2 & $1.03 \%$ \\
\hline CIN1 & 1 & $0.51 \%$ \\
\hline Granulomatous Cervicitis & 1 & $0.51 \%$ \\
\hline Total & 195 & $100.00 \%$ \\
\hline
\end{tabular}

\begin{tabular}{|c|c|c|}
\hline Diagnosis & $\begin{array}{c}\text { Mean Age } \\
\text { (Years) }\end{array}$ & $\begin{array}{c}\text { Standard } \\
\text { Deviation }\end{array}$ \\
\hline $\begin{array}{c}\text { Non- } \\
\text { neoplastic }\end{array}$ & 40.72 & 8.56 \\
\hline Pre-neoplastic & 49.79 & 10.76 \\
\hline \multicolumn{2}{|r|}{ Table 3: Mean Age and Standard } \\
Deviation of Lesions of Cervix
\end{tabular}




\begin{tabular}{|c|c|c|c|}
\hline Symptoms & $\begin{array}{c}\text { Chronic } \\
\text { Cervicitis }\end{array}$ & Dysplasia & CIN \\
\hline $\begin{array}{c}\text { White Discharge With/ } \\
\text { Without Lower } \\
\text { Abdominal Pain }\end{array}$ & 86 & 5 & 0 \\
\hline Lower Abdominal Pain & 48 & 4 & 0 \\
\hline $\begin{array}{c}\text { Abnormal } \\
\text { Bleeding/Spotting }\end{array}$ & 26 & 2 & 1 \\
\hline $\begin{array}{c}\text { Post-Menopausal } \\
\text { Bleeding }\end{array}$ & 15 & 3 & 3 \\
\hline Pyometra 4able 4: Clinical Presentation of Benign \\
Lesions of Cervix
\end{tabular}

\begin{tabular}{|c|c|c|}
\hline Gravida & Non-Neoplastic & Pre-Neoplastic \\
\hline $0-2$ & $73(41.4 \%)$ & $6(31.57 \%)$ \\
\hline $3-4$ & $89(50.56 \%)$ & $8(42.1 \%)$ \\
\hline$>5$ (grand multipara) & $14(7.9 \%)$ & $5(26.31 \%)$ \\
\hline \multicolumn{2}{|c|}{ Table 5: Distribution of Gravida } \\
\hline
\end{tabular}

\begin{tabular}{|c|c|c|c|c|c|}
\hline $\begin{array}{l}\text { Study } \\
\text { (Place) }\end{array}$ & Period & $\begin{array}{l}\text { Total } \\
\text { Cases }\end{array}$ & $\begin{array}{c}\text { Non- } \\
\text { Neoplastic } \\
\text { Cases (\%) } \\
\text { Neoplastic } \\
\text { Cases (\%) } \\
\end{array}$ & $\begin{array}{l}\text { Most Common Non- } \\
\text { Neoplastic Lesion-CC } \\
\text { Cases (\%) }\end{array}$ & Remarks \\
\hline $\begin{array}{l}\text { Olutoyin[2] }^{2} \\
\text { (Nigeria) }\end{array}$ & $\begin{array}{c}10 \text { yrs. } 1900- \\
1999\end{array}$ & 400 & $\begin{array}{c}150(32.5 \%) \\
250(62.5 \%)\end{array}$ & $\begin{array}{c}123 \\
(82 \%)\end{array}$ & 5 cases of granulomatous \\
\hline $\begin{array}{c}\text { FN } \\
\text { Nwachokor }{ }^{[3]} \text { (Nigeria) } \\
\end{array}$ & $\begin{array}{c}7 \text { yrs. } \\
2005-2011\end{array}$ & 176 & $\begin{array}{l}99(56.3 \%) \\
78(43.7 \%)\end{array}$ & $\begin{array}{c}44 \\
(44.44 \%)\end{array}$ & - \\
\hline $\begin{array}{c}\text { Aravind P } \\
\text { (Karnataka) }\end{array}$ & $\begin{array}{c}2 \text { years } \\
(2008-10)\end{array}$ & 1038 & $\begin{array}{c}1015 \\
(97.8 \%) \\
23(2.21 \%)\end{array}$ & $\begin{array}{c}742 \\
(73.2 \%)\end{array}$ & - \\
\hline $\begin{array}{l}\text { Naveen BJ[4] } \\
\text { (Telangana) }\end{array}$ & $\begin{array}{c}2 \text { years } \\
(2013-14)\end{array}$ & 1052 & $\begin{array}{c}830 \\
(78.89 \%) \\
222(21.1 \%) \\
\end{array}$ & $698(76.79 \%)$ & Studied adaptive lesions \\
\hline $\begin{array}{l}\text { Srinivani S[5] } \\
\text { (Tamil Nadu) }\end{array}$ & $\begin{array}{c}3 \text { years } \\
(2012-15)\end{array}$ & 794 & $\begin{array}{l}633(79.7 \%) \\
161(20.3 \%) \\
\end{array}$ & $\begin{array}{c}300 \\
(37.9 \%)\end{array}$ & Included prolapse \\
\hline $\begin{array}{c}\text { Present study } \\
\text { (Madhya Pradesh) } \\
(2015)\end{array}$ & $\begin{array}{l}20 \text { months } \\
\text { (Jan 2014 - } \\
\text { Aug 2015) }\end{array}$ & 395 & $\begin{array}{l}195(52 \%) \\
180(42 \%)\end{array}$ & $\begin{array}{c}175 \\
(46.67 \%)\end{array}$ & $\begin{array}{l}\text { Excluded prolapse, } \\
\text { one case of } \\
\text { granulomatous cervicitis }\end{array}$ \\
\hline & Table 6: Var & Studic & their Fin & $O P$ & \\
\hline
\end{tabular}

\begin{tabular}{|c|c|c|c|c|}
\hline Studies & Peak Decade & $\begin{array}{c}\text { Age } \\
\text { Range }\end{array}$ & $\begin{array}{c}\text { Mean } \\
\text { Age }\end{array}$ & Most Common Symptom \\
\hline Olutoyin G[2] & $\begin{array}{c}4^{\text {th }}(34.5 \%) \text { followed by } 3^{\text {rd }} \\
(30 \%) \& 5^{\text {th }}(18.7 \%)\end{array}$ & $20-69$ & - & - \\
\hline Aravind $\mathrm{P}[6]$ & 4 rth $(47 \%)$ & - & - & $\begin{array}{c}\text { White discharge per vagina }(26.6 \%) \text { followed } \\
\text { by mass per vagina }(21.08 \%)\end{array}$ \\
\hline $\begin{array}{c}\text { FN } \\
\text { Nwachokar[3] } \\
\end{array}$ & $\begin{array}{c}4^{\text {th }}(33.7 \%) \text { followed by } 5^{\text {th }} \\
(23.9 \%) \& 3 \text { rd }(21.7 \%)\end{array}$ & $20-89$ & $54.9+4.6$ & - \\
\hline Naveen BJ ${ }^{[4]}$ & 4 rth & - & - & $\begin{array}{c}\text { Excessive vaginal bleeding ( } 45.7 \%) \text { followed by } \\
\text { mass per vagina }(31.8 \%)\end{array}$ \\
\hline Srivani S[5] & 5 rth & $20-79$ & - & - \\
\hline Present Study & $\begin{array}{l}4^{\text {th }}(40.3 \%) \text { followed by } 3^{\text {rd }} \\
(35.22 \%) \text { and } 5^{\text {th }}(5.58 \%)\end{array}$ & $22-65$ & $40.8+8.6$ & $\begin{array}{c}\text { White discharge (47.69\%) followed by lower } \\
\text { abdominal pain (26.66\%) }\end{array}$ \\
\hline
\end{tabular}

\section{DISCUSSION}

We observed a wide range of histomorphological lesions among study of benign cervical lesions. In present study, chronic cervicitis and CIN cases had lower reported cases than expected from the population in considering that neoplastic cases were almost equal to non- and pre-neoplastic cases ( $48 \%$ vs $52 \%$ ) in a period of 20 months. The reason attributed to this is that most cases in our environment go unreported. In addition, it is also important to note that most cases are treated empirically by physicians or by self-medication.

Therefore, only few difficult cases would present at the Gynaecological Clinic for proper evaluation when symptoms are recurrent and/or persistent. Also there is minimal reporting of CIN cases in our scenario due to lack of specific symptomology in patients, social inhibitions to report gynaecological problems and lack of effective screening program in place. Thus, the gap was quite narrow highlighting the fact that more awareness, screening and regular follow-up could widen the gap and tilt graph favourably more towards the benign spectrum.

With regard to spectrum of lesions Olutoyin G,[2] FN Nwachokor,[3] Naveen Kumar BJ ${ }^{[4]}$ and Srivani Saravanan[5] reported $38.5 \%, 56.3 \%, 78.86 \%$ and $79.9 \%$ cases of benign lesions respectively among all cervical lesions reported in their respective study groups compared to $52 \%$ cases in present study.

The lower proportions of non-neoplastic lesions by Olutoyin $\mathrm{G}^{[2]}$ may be due to the fact that the study was done in 
1990s when both education, awareness and health facilities were inadequate compared to present times.

The increased proportion of benign lesions by Srivani Saravanan ${ }^{[5]}$ and Naveen Kumar BJ ${ }^{[4]}$ is understood by the fact that both studies were conducted beyond 2010 closer to present study as well as the South Indian population under consideration has better literacy rate, socioeconomic standing and health care facilities than central India, the setting of present study.

Olutoyin G[2] FN Nwachokor,[3] Aravind Palladily,[6] Srivani Saravanan[5] and Naveen Kumar BJ ${ }^{[4]}$ observed chronic nonspecific cervicitis as the most common lesion with $82 \%$, $72.2 \%, \quad 76.79 \%, 37.9 \%$ and $97.3 \%$ cases respectively compared to $89.7 \%$ cases in present study.

Thus, it was similar to all studies except that by Srivani $S$ et al,[5] because cervical prolapse was included in their study group unlike the present study which relatively decreased the chronic cervicitis proportions. The increased incidence of chronic cervicitis by Naveen Kumar BJ ${ }^{[4]}$ may be attributed to increased reporting and awareness among females in present times, especially in South India the study area of aforementioned research.

With respect to granulomatous lesions only Olutoyin $\mathrm{G}^{[2]}$ reported 5 cases in Nigeria compared to 1 case in present study. These were most probably due to tuberculosis, which had a high prevalence of 250/1 lack population in Nigeria and 10th rank among the 22 high-burden TB countries in the world. [7]

Also tuberculosis is seldom known to infect cervix, though fallopian tubes are its common site. Though central India has high rate of tuberculosis particularly in association with HIV, it seldom comes to notice as other health problems mask its incidence.

Comparative evaluation has been tabulated in Table 6 and Table 7.

For benign lesions of cervix, the peak age group was 4th decade in studies by Olutoyin G,[2] FN Nwachokar,[3] Aravind $\mathrm{P}^{[6]}$ and Naveen $\mathrm{BJ}^{[4]}$ similar to present study barring that by Srivani $S^{[5]}$ observed peak in 5 th decade. This can be explained by the fact that she included cervical prolapse in study group, which might have skewed the peak to 5 th decade.

In our study, the mean age of non-neoplastic lesions was 40.7 years compared to 49.7 in pre-neoplastic group almost a decade later. We inferred that women are increasingly being health conscious and awareness regarding gynaecological treatment has increased significantly among the relatively younger generation. Though social and economic barriers still hound many to seek health care facilities apart from obstetric causes

The most common clinical presentation was white discharge per vaginum similar to Aravind $P,[6]$ and in contrast to that of Naveen BJ ${ }^{[4]}$ - abnormal bleeding. We could not explain the reason for this contrast. However, findings of present study were consistent with symptomology mentioned in standard literature.

Benign lesions of cervix consisting mainly of chronic cervicitis is a precursor for carcinogenesis, as repeated and persistence insult to cervical epithelium leads to metaplasia and subsequently neoplasia as well, thus screening and early detection of same is pertinent for control of cancers of cervix uteri.
There is an urgent need for regular and effective cervical screening program as well as HPV vaccination should be included in universal immunization program in India. Vaccine is expensive and cytology based screening is resource intensive in terms of infrastructure, equipment and manpower. As a result, death and disability from this cancer are high including India.[8]

Women being the main caretaker of children as well as an almost equal economical contributor in current era need to be properly screened for malignancies and detecting cases in preneoplastic and curable stage will go a long way in reducing morbidity and mortality.

We observed that women were reluctant in approaching health clinics for gynaecological symptoms. Also none of the cases had HPV vaccination before the first sexual encounter. Though awareness regarding the same is increasing, cost and social stigma are the main deterrent factors for females in current scenario. History regarding number of sex partners and sexual history of their male counterparts was also unreliable in our study group.

Though there are many national programs successfully running for obstetrics cases, same is lacking for gynaecological problems.

The WHO recommended target group for HPV vaccination is 9-13 year old girls who have not yet become sexually active.(9) Including school girls in HPV vaccination program in future will help reduce the burden of cervical lesions. Sensitisation of parents is essential for undertaking such programs and large scale awareness programs need to be implemented highlighting its long-term health benefits. Especially designed messages are essential to educate communities keeping in mind social yardsticks and education of people. Parents, specifically illiterates need to be sensitively communicated the reason for targeting girl child. Subsequently, non-school going girls should be included more so because low socioeconomic and poor hygiene is a known risk factor for cervical pathologies.

Early screening of the disease through cytology has considerably reduced morbidity and mortality from the disease in the developed world.[10] Cervical cancer causes loss of productive life both due to early death as well as prolonged disability. Additionally, the high medical costs that are incurred by families due to cervical cancer (especially since most cases in developing countries are diagnosed at advanced stages when treatment is costly but prognosis poor), further impoverish individuals and communities.(11) Thus, detecting precursor lesions in nascent stage could reduce the cancer burden considerably.

In finance constrained setting like ours, cost of vaccine as well as operational cost for delivery need also to be taken into consideration during planning process itself and will be a critical step in the decision-making process.

Due to difficulties of access and affordability, compliance to and follow-up of treatment is much worse for women of low socioeconomic strata leading to further morbidity and mortality from the disease.

\section{CONCLUSION}

Large scale screening programs for target populations should be organised to reduce the long-term morbidity, mortality and socioeconomic burden related with cervical lesions. 
Also increasing literacy rate, personnel hygiene, socioeconomic strata, use of contraceptive measures to reduce parity will be highly instrumental in tackling the current and future burden of cervical cancers.

We hope and recommend that this study will lay the foundation for policy makers to effectively prevent and control cervical cancers in future as well as improve the present scenario.

\section{ACKNOWLEDGEMENT}

I would like to acknowledge the contribution of Mr. B. S. Mathur, Mr. Ashok Gurjar, Mrs. Jyoti, Mr. Suresh Malviye and Mr. B. K. Shrivastava.

\section{ABBREVIATIONS}

CIN - Cervical Intraepithelial Lesions.

\section{REFERENCES}

1. Mostafa MG, Srivannuboon S, Rachanawutanon M. Accuracy of cytological findings in abnormal cervical smears by cytohistologic comparison. Indian J Pathol Microbiol 2000;43(1):23-9.

2. Omoniyi-Esan OG, Osasan SA, Ojo OS. Non-neoplastic diseases of the cervix in Nigerians: a histopathological study. Afr Health Sci 2006;6(2):76-80.

3. Nwachokor FN, Forae GC. Morphological spectrum of nonneoplastic lesions of the uterine cervix in Warri, SouthSouth, Nigeria. Niger J Clin Pract 2013;16(4):429-32.

4. Kumar NBJ, Annam V. Clinico-pathological study of nonneoplastic lesions of uterine cervix with their histopathological categorization. International Journal of Science and Research Paper ID: SUB151714, 2015;4(2):2094-8.
5. Saravanan S, Arnold J, Arul P. Histomorphological spectrum of lesions of the cervix. A retrospective study in a tertiary care hospital. Journal of Evolution of Medical and Dental Sciences 2015;4(59):10326-9.

6. Pallipady A, Illanthody S, Vaidya R, et al. A Clinicomorphological spectrum of the non-neoplastic lesions of the uterine cervix at AJ Hospital, Mangalore. Journal of Clinical and Diagnostic Research 2011;5(3):546-550.

7. Ifeanyi OT, Odunayo 00, Akinpelumi AV. Kinetics and demographic studies of tuberculosis among patients attending national Tuberculosis and Leprosy Control Programme, Owo Centre, Ondo State, Nigeria. African Journal of Microbiology Research 2015;9(6):343-347.

8. Parkin DM, Bray F, Ferlay J, et al. Global cancer statistics, 2002. CA: A Cancer Journal for Clinicians 2005;55(2):74108.

9. WHO. Comprehensive cervical cancer prevention and control: a healthier future for girls and women. Geneva: WHO Press 2013.

10. Miller AB, Chamberlain J, Day NE, et al. Report on a workshop of the UICC project on evaluation of screening for cancer. International Journal of Cancer 1990;46(5):761-9.

11. Bishop A, Sherris J, Tsu VD, et al. Cervical dysplasia treatment: key issues for developing countries. Bulletin of the Pan American Health Organisation 1996;30(4):378-86. 